\title{
Research and Application of Educational Informatization Measurement Index for Local Colleges and Universities
}

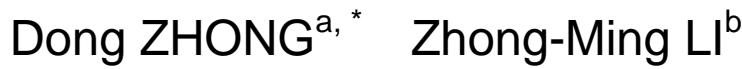 \\ School of electronic and information, Hubei University of Science and Technology, \\ Xianning, Hubei 437100, China \\ aemail:zhongdong0129@163.com, bemail:27820424@qq.com
}

Keywords: Educational informatization, Local colleges, Measurement index.

\begin{abstract}
Combining theoretical research with practical application, this paper analyzes and study the problems in the development of informatization process in local colleges and universities based on the analysis of the status quo of the development of informatization in local colleges and universities, and then design an index system of measuring and evaluating the level of educational informatization in local colleges and universities. Through the study of this article, it is beneficial to strengthen the educational informatization of local colleges and universities, and promote the rapid development of informatization in local colleges and universities.
\end{abstract}

\section{Introduction}

With the continuous development of informatization, educational informatization, especially the university educational informatization construction, has attracted worldwide attention. The informatization of education in local colleges and universities is the basis and propeller of social informatization, and it is also the only way to achieve educational informatization. Therefore, it is of great significance to carry out the evaluation of educational informatization in local colleges and universities. The research on the index system of educational informatization in local colleges conforms to the operating rules of educational information systems. The informatization of education in local colleges and universities is a subsystem of social informatization. It is an organic whole with a specific structure and function. The indicator system should be a measure that reflects the overall organic characteristics and internal changes. Because different index reflect different conditions and performances, one or several index can only observe the system from one aspect, and obviously cannot reflect the overall situation and the entire process of system operation and evolution. When evaluating a system, only one or several aspects of the system are compared and analyzed. The conclusions obtained are also one-sided and sometimes even false and impractical. Therefore, it is necessary to inspect the overall operating conditions and development changes of the various components of the system of educational informatization in the local college comprehensively, and it is necessary to establish a suitable index system.

Establishing an evaluation system for the educational informatization of local colleges and universities is a realistic requirement for promoting the development of educational informatization. The Ministry of Education of China has proposed the goal of using modernization of higher education to drive the modernization of education. However, the research of informatization of university education in our country has just started. There are few studies on the index system and the theories and methods of evaluation about educational informatization in local colleges and universities. There is a lack of scientific and systematic quantitative data. Existing research is scattered, Therefore, it is necessary to establish an evaluation system for the educational informatization of local colleges and universities in our country, and to form a technical method for comparing the level and development of informatization, and to quantify the level, development process, and problems of educational informatization of college education in all areas of our country, and it helps to understand the current situation of educational informatization in local colleges and universities in our country, and study the development law of educational informatization in local colleges and universities in our country. Measure is a common method of 
analyzing and understanding things. Measuring the level of informatization of local colleges and universities will help strengthen the educational informatization of local colleges and universities and promote the rapid development of educational informatization in local colleges and universities.

\section{Problems in the Process of Informatization in Local Colleges and Universities}

Although the educational informatization construction in local colleges and universities in our country has a good start and a certain foundation, it has the same features as the educational informatization construction of university in other countries and also has its own unique characteristics. As the educational informatization of local colleges and universities in our country still remains at the stage of the construction of large-scale basic network and information resource .so the problems existing in the educational informatization construction in local colleges and universities in our country are generally expressed in the following aspects:

\section{Backward Ideas and Thoughts}

The informatization of education in local colleges and universities is a brand-new job and a systematic project. The development of educational informatization in local colleges and universities is the basis and conditions for promoting the modernization of education in local colleges and universities. It is the internal driving force for the comprehensive reform and development of local college education. It will Break through the limitations of time and space in traditional local college education, promote the popularization and lifelong of education in local colleges and universities, and make a revolutionary change in local college education. Accelerating the development of educational informatization in local colleges and universities is of great significance for a country which is relatively weak in local college education. However, at present, the majority of educators and administrators still have a big gap in understanding the issue of educational informatization in local colleges and universities in our country. The lag in ideological concepts has affected the development of educational informatization in local colleges and universities in our country. For example, the idea of dispensable informatization in local colleges and universities, and the idea of "technical determinism" in the educational informatization of local colleges and universities, as well as the traditional view of time, space, education, education, teacher-student, and quality-benefit of education in local colleges and universities will all influence and restrict the development of educational informatization in local colleges and universities.

\section{Lack of Awareness of Information Services}

Digital data needs to be collated, screened, classified, and refined by professionals in order to become useful information. Only processed information is useful and disordered information can only be seen as digital garbage. At present, almost no local information institutions or expert advisory groups have been set up in local information institutions in China, which has brought inconvenience to the use of information resources. And for educational institutions like Harvard University in the United States, which have a relatively high level of informatization, set up a dedicated information technology service department. Its role is to provide users with computer network technology services, help teachers and students collect and organize the required information, provide counseling services for teachers and students, and manage and control the security and quality of networks and data.

\section{Insufficient Capital Investment}

In recent years, in spite of the government's determination to speed up the pace of educational informatization in local universities and increase investment.. Local institutions have also adopted multiple channels to raise funds for the annual use of information technology in local universities. The increase in funding is large. On the whole, due to the weak foundation of education in local universities, and the limited financial resources, the total investment in local educational informatization is still insufficient. This is especially true for normal universities, and their funding 
is far from sufficient for their needs of educational information. Therefore, the lack of funding is still an important factor restricting the informatization of local universities.

In addition, there are some problems that are also constraining the development of information technology in local universities. For example, the cost of informatization is too high, the results of informatization are difficult to evaluate, and the education industry's information standards are immature. If these problems cannot be solved well, they will inevitably affect the progress of educational informatization in local universities.

\section{Construction of an Index System to Measure and Evaluate the Level of Educational Informatization in Local Universities}

Measure is a commonly used method of analyzing and understanding things. Measuring the level of informationalization of local universities will help strengthen the informatization of local universities and promote the rapid development of local colleges' informatization. This passage constructs a system of index for the measurement of educational informatization in local universities (as shown in Table 1). The main evaluation index include infrastructure construction, information resources construction, information technology education, information application, application effect, education website, education growth, comprehensive management, talent team, and investment. The infrastructure construction reflects the hardware support conditions and environment for the education informatization of local universities. The construction of information resources and the application of information reflect the level of information construction and application of local universities. Funding and information technology education is a powerful guarantee for ensuring the continuous improvement and development of educational informatization. The application effect reflects the efficiency and effectiveness of the educational information system of local colleges and universities. The indicator system has 8 first-level index and 34 second-level index, including both qualitative and quantitative index.

Among them, infrastructure construction index are reflected in three aspects: the overall infrastructure construction of the university (such as the coverage rate of Campus network, the speed of campus network, the rate of computer networking, proportion of multimedia classrooms), student's infrastructure construction (such as the rate of Internet access in students' dormitories, the average number of students' computers, telephone penetration rate of student dormitories, limited TV interface rate of student dormitories), and teachers' infrastructure construction (such as the average number of teachers' computers, average number of Workers' computers).Index for the construction of information resources include information resource ownership (such as possession of e-books, possession of CD-ROM databases, possession of http and ftp resources, and level of information retrieval systems) and usage of information resources (such as the ownership rate of Multimedia software and courseware, online teaching resources).Information technology education index are reflected in two aspects: the process of information technology education (such as Proportion of students on the computer, proportion of information courses of non-information professional students) and the results of information technology education (such as the pass rate of graduates' computer second-level); The application index of informatization include the construction of campus card, the remote education system and the online borrowing and inquiring system of books. The application effect index are measured from three aspects: the degree of students' information technology utilization, the utilization degree of teachers' information technology and the utilization degree of staff information technology; Comprehensive management Index mainly includes the university senior leadership's emphasis on educational informatization degree, university of all kinds of information management rules and regulations and the complement of the university information management situation of the implementation of the rules and regulations; Talent team index including the result of the talent training (such as the pass rate of CET4 for graduates), the utilization degree of student information technology, the utilization degree of teacher information technology, the utilization degree of staff information technology and so on ; In order to be able to better measure the local universities educational informatization construction 
situation, This article has increased the index of investment input ,and the Index is reflected from both the average cost of cultivation and the growth rate of the average cost of training.

Table 1. Index System of Measurement of Educational Informatization in Local Colleges and Universities

\begin{tabular}{|c|c|c|}
\hline $\begin{array}{l}\text { Serial } \\
\text { number }\end{array}$ & $\begin{array}{l}\text { First-level } \\
\text { index }\end{array}$ & Secondary index \\
\hline 1 & $\begin{array}{l}\text { infrastructure } \\
\text { construction }\end{array}$ & $\begin{array}{l}\text { the coverage rate of Campus network, the rate of Internet } \\
\text { access in students' dormitories and the rate of computer } \\
\text { networking, The average number of students' computers, the } \\
\text { average number of teachers' computers, average number of } \\
\text { Workers' computers, proportion of multimedia classrooms, } \\
\text { telephone penetration rate of student dormitories, and limited } \\
\text { TV interface rate of student dormitories }\end{array}$ \\
\hline 2 & $\begin{array}{l}\text { information } \\
\text { resources } \\
\text { construction }\end{array}$ & $\begin{array}{l}\text { the ownership rate of Multimedia software and } \\
\text { courseware ,online teaching resources, possession of e-books, } \\
\text { CD-ROM database ownership, httP and ftP resource } \\
\text { ownership, and the level of information resource retrieval } \\
\text { system }\end{array}$ \\
\hline 3 & $\begin{array}{l}\text { information } \\
\text { technology } \\
\text { education }\end{array}$ & $\begin{array}{l}\text { Proportion of students on the computer, proportion of } \\
\text { information courses of non-information professional students, } \\
\text { and the graduates' pass rate of Computer level two test }\end{array}$ \\
\hline 4 & $\begin{array}{l}\text { Informatizatio } \\
\mathrm{n} \text { application }\end{array}$ & $\begin{array}{l}\text { Campus card construction, distance education system, the } \\
\text { situation of library lending and inquiry system }\end{array}$ \\
\hline 5 & $\begin{array}{l}\text { the effect of } \\
\text { application, }\end{array}$ & $\begin{array}{l}\text { the utilization degree of student information technology, the } \\
\text { utilization degree of teacher information technology, the } \\
\text { utilization degree of staff information technology }\end{array}$ \\
\hline 6 & $\begin{array}{l}\text { comprehensive } \\
\text { management }\end{array}$ & $\begin{array}{l}\text { The attention of the leadership of local colleges and } \\
\text { universities in educational informatization, the completeness } \\
\text { of various types of information management rules and } \\
\text { regulations in local colleges, and the implementation of } \\
\text { information management systems in local colleges and } \\
\text { universities }\end{array}$ \\
\hline 7 & talent team & $\begin{array}{l}\text { the pass rate of CET4 for graduates, the penetration rate of } \\
\text { teacher's informatization skills, and the penetration rate of } \\
\text { staff's informatization skills }\end{array}$ \\
\hline 8 & investment & Average cost of cultivation, growth rate of cost per student \\
\hline
\end{tabular}




\section{Conclusions}

Based on the study of domestic and foreign educational informatization and the informatization of higher education, according to designing guidelines and principles of the indicator system, using the methods of research in related disciplines such as economics, education, applied statistics, and systems engineering, this article has designed a set of index for the measurement of educational informatization in local colleges and universities.

\section{Acknowledgment}

The authors gratefully acknowledge the financial support for this work provided by the Program of the humanities and social science project of Hubei education department, No. 16Q259 and 18Q164, the Natural Science Foundation of Hubei Province, Grant No. 2016CFB515, the National Natural Science Foundation of China (NSFC) under the Grant No. 61575148, the Dr. Start-up fund of Hubei University of science and technology No. BK1524, the colleges and universities of Hubei Province innovation and entrepreneurship training plan, No.201710927006Z, the Team Plans Program of the Outstanding Young Science and Technology Innovation of Colleges and Universities in Hubei Province, Grant No. T201817, the teaching reform program for Chinese and foreign cooperation of Hubei University of science and technology, No.2017-ZYA-002.

\section{Reference}

[1]Xu Lin. the research of educational informatization. Southwest University of Political Science and Law.2004

[2] Kong Fushi. Theoretical research and empirical analysis of informatization in higher education: (Ph.D. thesis). Wuhan: Wuhan University of Technology University. 2013

[3]Gong Libo. Discussion on the Construction and Management of University Informatization. educational informatization Forum.2014

[4]Liu Xidong, Yu Feng.The significance and countermeasures of the informatization construction in colleges and universities. Journal of Shenyang Jianzhu University. 2015

[5]Guo Wenge. Indigenization: Status Quo and Development Trend of International Higher educational informatization. Open Education Research. 2012

[6]Zhao Quanchao, Zhao Guojie, Wang Ju. Research on the Measurement and Comprehensive Evaluation of College educational informatization. College Library and Information.2014 